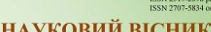

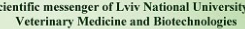

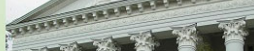

(11)

СЕРІя "СЛЬСБКОГОСПОДАРСКК НАУКГ"

(3). Том 23 № 95

2021
Науковий вісник Дьвівського національного університету ветеринарної медицини та біотехнологій імені С.3. Гжицького. Серія: Сільськогосподарські науки

\section{Scientific Messenger of Lviv National University} of Veterinary Medicine and Biotechnologies. Series: Agricultural sciences

UDC 639.3 .03

\title{
Watercourses of the Carpathian Biosphere Reserve as a habitat, reproduction and conservation of fish gene resources
}

\section{V.P. Terpay \\ Article info \\ Received 12.07.2021 \\ Received in revised form 12.08 .2021 \\ Accepted 13.08.2021}

Transcarpathian scientific-research station lososivnytstva and conservation of endangered species NAAS Institute of Fisheries, Mukacheve, Ukraine

Transcarpathian scientific-research station lososivnytstva and conservation of endangered species NAAS Institute of Fisheries, Uzhhorodska Str., 165, Mukacheve 89600, Ukraine. Tel.: +38-095-260-75-00 E-mail:trsif@ukr.net
Terpay, V. P. (2021). Watercourses of the Carpathian Biosphere Reserve as a habitat, reproduction and conservation of fish gene resources. Scientific Messenger of Lviv National University of Veterinary Medicine and Biotechnologies. Series: Agricultural sciences, 23(95), 160-166. doi: $10.32718 /$ nvlvet-a9524

Natural watercourses, their forage base, and ichthyofauna of the Carpathian Biosphere Reserve of the Transcarpathian region have been studied. Information on the species composition is given, the names and genus of some of the specimens are specified. The systematic structure is reflected, the functional role of roundworms and fish in the studied ecosystem, dominant and endangered species are determined. Their geographical distribution in different zones of watercourses, structural-comparative analysis with the species registered in the Transcarpathian region are carried out. It is established: a characteristic feature of the ichthyocenosis is the presence of a significant number of salmon and aboriginal species. The urgency of research - global warming, human activities change the hydroecosystem of the reserve, have a negative impact on aboriginal fish species, which are indicators of changes in hydrological regime and microclimate, lead to the settlement of their areas indigenous. In total, we recorded 42 species belonging to 7 series, 11 families, 33 genera in the studied water areas. Additionally, 12 undescribed were identified. The growth of the total number of species by $66.67 \%$ was due to allochtons. Emphasis was placed on the need for further genetic research, which could be a source of additional information on fish biodiversity in the Carpathian Biosphere Reserve and in the Tisza River, a tributary of the Danube.

Key words: Carpathian Biosphere Reserve, natural watercourses, ichthyofauna, global warming, ecosystem.

\section{Водотоки Карпатського біосферного заповідника як середовище існування, відтворення і збереження генофондових ресурсів риб}

\author{
В. П. Терпай
}

Закарпатська науково-дослідна станція лососівництва та відтворення зникаючих риб Інституту рибного господарства НААН, м. Мукачеве, Закарпатська область, Украӥна

Досліджено природні водотоки, їхню кормову базу та іхтіофауну Карпатського біосферного заповідника Закарпатської області. Подано відомості про видовий склад, уточнено назви і родову належність частини екземплярів. Відображено систематичну структуру, визначено функиіональну роль круглоротих і риб у досліджуваній екосистемі, домінуючі та зникаючі види. Здійснено їх географічний розподіл у різних зонах водотоків, структурно-порівняльний аналіз із видами, що зареєстровані в Закарпатській області. Встановлено: характерна особливість іхтіоценозу - наявність ще досить значної кількості лососевих $і$ аборигенних видів. Актуальність досліджень - глобальне потепління, діяльність людини змінюють гідроекосистему заповідника, чинять негативний вилив на аборигенні види риб, які є індикаторами змін гідрологічного режиму і мікроклімату, призводять до заселення ӥхньої територій алохтонними. Загалом у досліджуваних акваторіях ми зафіксували 42 види, що належать до 7 рядів, 11 родин, 33 родів. Додатково ідентифікували 12 неописаних. Ріст загальної кількості видів на 66,67 \% відбувся за рахунок алохтонів. Наголо- 
шено на необхідності подальших генетичних досліджень, щзо може бути джерелом додаткової інформації про біологічне різноманіття риб у Карпатському біосферному заповіднику і у ріиі Тиса, притоиі Дунаю.

Ключові слова: Карпатський біосферний заповідник, природні водотоки, іхтіофауна, глобальне потепління, екосистема.

Вступ

Територія шести масивів Карпатського біосферного заповідника (КБЗ) вирізняється максимальними (Мараморошський, Чорногірський, Свидовецький) i доходить майже до мінімальних (Долина Нарцисів) орографічних висот серед іхтіофауністичних районів, це найзволоженіший, 3 найгустішою гідромережею регіон України та Європи. Кузій - Трибушанський і Мараморошський прилягають до центральної садиби та річки Тиси. Більша частина їхнього водного дзеркала утворена системою гірських потоків і річок зі швидкою нерівномірною течією, порогами, 3 чітко вираженими меандруючими руслами. Належать до басейнів Чорної Тиси, Білої Тиси, Тересви, Тереблі, Кісви, Тиси. Виступають оселищем гідробіонтів, у тому числі й іхтіофауни, яка є ключовою та бере активну участь у кругообігу речовин еталонної екосистеми КБЗ. Вона характеризується досить високою різноманітністю, доброю збереженістю, водночас надзвичайно чутлива до глобальних змін клімату і діяльності людини. Крім того, є важливим аспектом охорони біорізноманіття, визначальною у функціонуванні гідробіоценозів не лише КБЗ, а й рік Тиса та Дунай. Однак аналіз наукових джерел показав, що питанню вивчення особливостей і стану іхтіофауни заповідника приділяється мало уваги. Відомості щодо видів вкрай обмежені. Наприклад, перше грунтовне дослідження рибних зведень розпочато у 90 роках минулого століття з виконанням проекту Глобального екологічного фонду "Збереження біорізноманіття Карпат" і оформлено книгою "Біорізноманіття Карпатського біосферного заповідника”, Київ, 1997, у додатку наведено 23 види круглоротих і риб. Нові роботи (Ф. Гамор, 2016; Я. Довганич та ін., 2019) інформують про поширення відповідно 26 і 30 видів. Водночас, у зв'язку з особливим природоохоронним статусом, дослідження стану окремого компоненту водної екосистеми КБЗ іхтіофауни потребує систематизованих відомостей щодо чисельності, співвідношення різних видів, вертикальної та просторової структури. Має теоретичне і практичне значення у встановленні основних закономірностей іiї організації, що важливо для прогнозування змін в окремих біотопах. Дозволяє оцінити функціонування екосистеми водойм заповідника, яке відбувається за участі, починаючи від найпростіших водних організмів бактерій та водоростей і закінчуючи однією із верхніх ланок трофічного ланцюга водних біоценозів рибами, земноводними та деякими наземними тваринами. Відтворювальні можливості популяцій аборигенних, раритетних і лососевих риб як ядра генофондових ресурсів річкової екосистеми Верхньо-Тисянського рибовідтворювального комплексу (Terpai, 2018), що забезпечує цінною іхтіофауною ріки Тиса та Дунай.
Таким чином метою даної роботи було вивчити i встановити сучасний видовий склад та систематику, таксономію, номенклатуру і на цій основі впорядкувати новий перелік міног і риб природних водотоків масивів КБЗ. Проаналізувати географічний розподіл, зміни, визначити домінуючі види, функціональну роль іхтіоценозу у досліджуваній екосистемі.

\section{Матеріал і методи досліджень}

Дослідження проводили протягом 2017 - першої половини 2020 років екосистем проточних водойм Свидовецького (СВ); Чорногірського (ЧО); Мараморошського (MP); Угольсько-Широколужанського (УШ); Кузій-Трибушанського (КТ); Долини Нарцисів (ДН) масивів КБЗ. В процесі роботи використано маршрутно- експедиційні методи польових досліджень, спостереження, порівняння, контент - аналіз наукових джерел. Літопис природи КБЗ, том 1-45, інші документи та опитування працівників єгерської служби. Вилучений від браконьєрів улов інспекторами та матеріали Управління державного агентства рибного господарства у Закарпатській області. Результати вивчення нами іхтіофауни басейну ріки Тиса (Terpai, 2018; Terpay, 2019). Систематичне положення, латинські й українські назви риб і круглоротих подано за Мовчан Ю. В. (Movchan, 2011), Турянин I. I. (Turianyn, 1982), Міжнародним кодексом зоологічної номенклатури (Mizhnarodnyi kodeks zoolohichnoi nomenklatury, 2003).

\section{Результати та їх обговорення}

В адміністративному плані КБЗ з лотичними гідроекосистемами знаходиться в межах високогір'я Рахівського i Тячівського та низовини Хустського районів Закарпатської області. Розглянута територія належить до збережених і малопорушених, 3 властивим біотичним (3513 видів фауни) й ландшафтним різноманіттям. В їі природних водотоках 3 певними фізіологічно обумовленими коридорами відбувається розвиток іхтіофауни - за температурою води, мінералізацією, газовим режимом, $\mathrm{pH}$, вмістом біогенних, токсичних елементів, станом кормової бази та ін. Тому надаємо коротку характеристику місця мешкання типових представників. Встановлено, середня густота досліджуваної річкової мережі 2 км/км². Охоплює гірську, крім Хустянки, частину басейну річок Чорна Тиса, Біла Тиса, Тересва, Теребля, Кісва і нараховує 240 потоків та річок першого-п'ятого порядку загальною довжиною 551,8 км, що пов'язано з геологічними, орографічними особливостями будови території. Самі вони не входять, лише протікають в окремих місцях або по межах заповідних ділянок чи на невеликій відстані від них і впадають у головну артерію краю Тису (таблиця 1). 
Таблищя 1

Дані про водотоки Карпатського біосферного заповідника в розрізі масивів

\begin{tabular}{|c|c|c|c|c|c|}
\hline \multirow{2}{*}{ Назва масиву } & \multirow{2}{*}{$\begin{array}{l}\text { Кількість } \\
\text { допливів }\end{array}$} & \multirow{2}{*}{ Довжина в межах КБЗ, км } & \multicolumn{2}{|c|}{ Висота витоку, м н. р. м. } & \multirow{2}{*}{ Впадають у ріку } \\
\hline & & & найвищого & найнижчого & \\
\hline Свидовецький & 49 & 125,2 & 1640 & 750 & $\begin{array}{c}\text { Тиса } \\
\text { Ч. Тиса } \\
\text { Кісва }\end{array}$ \\
\hline Чорногірський & 33 & 114,5 & 1800 & 930 & Б. Тиса \\
\hline Мараморошський & 34 & 76,4 & 1880 & 780 & $\begin{array}{l}\text { Б. Тиса } \\
\text { Тиса }\end{array}$ \\
\hline Кузій-Трибушанський & 32 & 49,2 & 1400 & 660 & Тиса \\
\hline $\begin{array}{l}\text { Угольсько- } \\
\text { Широколузький }\end{array}$ & 91 & 175,5 & 1400 & 490 & $\begin{array}{l}\text { Тересва } \\
\text { Теребля }\end{array}$ \\
\hline Долина Нарцисів & 1 & 11,0 & 520 & 180 & Тиса \\
\hline Разом & 240 & 551,8 & - & - & - \\
\hline
\end{tabular}

Живлення усіх дощове, талими водами і частково підземними джерелами. Для більшості характерний порожисто-водопадний тип русла, середня швидкість течії 1,5-2 до 3 м/сек. Падіння у високогір'ї (7001300 м над рівнем моря) сягає 100 м/км, при виході 3 гір 10-20 м/км. Добре виражений паводковий режим 3 різким коливанням стоку води. Чітко виділяються 2 максимуми (березень-квітень, листопад-грудень) та 2 межені. Розподіл річного стоку: літо - 41-53\%, весна - 10-22, осінь - 11-15, зима - $18 \%$. За сучасним гідрологічним районуванням, за умовами річного стоку води на основі кривих Ендрюса належить до Карпатського гідрологічного району - показники, середнє / інтервал М модуль стоку л/с км² 19,6; Cv 0,32 (Horbachova \& Khrystiuk, 2016), верхів'я річки Мокрянка л/с км ${ }^{2} 40$. Льодовий покрив утворюється в кінці грудня, першій половині січня. Вода водотоків, що впадають у Білу Тису більш мінералізована, ніж тих, які впадають у Чорну Тису за рахунок аніону HCO3-, здебільшого гідрокарбонатно - кальцієва, рідше - гідрокарбонатно-натрієва або гідрокарбонатно-магнієва, першого, другого, іноді третього типів, прісна. Загальна кількість іонів 19,4 - 396,2 мг/дм³ Жорсткість 0,18 - 2,7 Тиса та 3,1 мг-екв/дм³ Хустець, тобто м'яка, крім потоків Заноговий, Соколине Бердо, Полонинський $(4,75-5,15$ мг-екв/дм³) середньої жорсткості. Вміст розчинених сполук заліза - 0,008 0,3 мг/дм ${ }^{3}$, нітратів - 0,75-5,6 мг/дм³. Концентрація розчиненого кисню у воді вище села Чорна Тиса $13,1 \mathrm{мг} /$ дм $^{3}$, біологічне споживання кисню БСК5 $1,7 \mathrm{мг} /$ дм $^{3}$, значення водневого показника $\mathrm{pH}$ становить 8,0 .

Активні температури по течії Тиси розподіляються таким чином: на вершинах витоку $1000 \AA C$, південно західних схилах 1500-2000®С, передгір”ї - 2500®С. Опади випадають, навпаки, високо в горах відповідно 2400, тобто 2 середньорічні норми та 900-1400 мм на території КБЗ.

Основна кормова база риб сформована угрупуваннями донних водоростей і безхребетними. Кількісні показники фітопланктону за чисельністю коливаються від 23,0 до 313 тис. кл/дм ${ }^{3}$, за біомасою $0,045-$

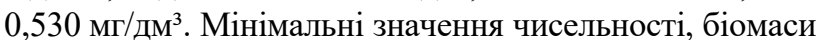
і видового багатства у високогірних водотоках, максимальні - в передгірних, низинних. Донні безхребетні розміщуються також залежно від висоти протікання водотоку над рівнем моря, середні показники наведено у відсотках до загальної чисельності (табл. 2).

Таблиця 2

Питома маса від загальної чисельності донних безхребетних у водотоках басейну і річці Тиса, \%

\begin{tabular}{|c|c|c|c|c|}
\hline \multirow{2}{*}{ Донні безхребетні } & \multicolumn{4}{|c|}{ Зона водотоку, висота над рівнем моря,м } \\
\hline & $>800$ & $800-300$ & $300-150$ & $<150$ \\
\hline Веснянки і амфіподи & - & - & 1,0 & - \\
\hline Німфи поденки & 26,0 & 31,0 & 21,0 & 6,0 \\
\hline Веснянки & 18,0 & - & - & - \\
\hline Німфи веснянок & - & 8,0 & - & - \\
\hline Рівноногі раки & 26,0 & 13,0 & - & 6,0 \\
\hline Личинки ручейників & 15,0 & 20,0 & 28,0 & 22,0 \\
\hline Комарі-дзвінці & 8,0 & - & 35,0 & 28,0 \\
\hline Личинки комарів-дзвінців & - & 21,0 & - & - \\
\hline Брюхоногі молюски & 5,0 & 5,0 & 7,0 & - \\
\hline Малощитинкові черви & - & - & 8,0 & 22,0 \\
\hline Інші & 2,0 & 2,0 & - & 16,0 \\
\hline Всього & 100,0 & 100,0 & 100,0 & 100,0 \\
\hline
\end{tabular}

3 макрозообентосу ефемероптери переважають у Чорній та Білій Тисі, Тисі, Говерлі (23-62 \%), трихоноптери домінують в річках Тиса, Брустурянка, Красна, Мокрянка (39-59 \%), амфіподи в р. Мала Уголька
(41-52 \%). За показниками біомаси малопродуктивні Теребля, Тересва, Чорна Тиса (2,96-9,50 г/м), середньопродуктивні Говерла, Біла Тиса, Брустурянка, 
Мокрянка, Красна (10,22-17,58 г/м), високопродуктивні Тиса, Мала Уголька (19,47-83,84 г/м).

Підсумовуючи наведене, бачимо, що зазначені обставини мають вплив на формування видової насиченості, поширення та динаміку чисельності окремих популяцій іхтіофауни КБЗ. Ці суто водні істоти належать до хребетних, пойкілотермних тварин (підтип Vertebrata), що включає клас круглоротих (Cyclostomata) і кісткових риб (Osteichthyes). Тіло має зовнішній скелет, утворений лускою. Запліднення зовнішнє.
Наші дослідження виявили деякі відмінності від описаних у літературі, доказали присутність у КБЗ 34 видів круглоротих і риб, зарахованих до автохтонних. У таблиці 3 наводимо уточнений та конкретний видовий склад в розрізі масивів. Наукові назви включаючи латинські, приведені у відповідність до вимог "Міжнародного кодексу зоологічної номенклатури, 2003" таксономічного статусу.

\section{Таблиця 3}

Інвентаризаційний список автохтонних міног і риб водотоків КБЗ в розрізі масивів

\begin{tabular}{|c|c|c|c|c|c|c|c|}
\hline & \multirow{2}{*}{ Таксономічний статус, назва виду (українською, латинською) } & \multicolumn{6}{|c|}{ Назва масивів } \\
\hline & & $\mathrm{CB}$ & ЧO & MP & УШ & KT & ДН \\
\hline \multirow{5}{*}{1} & Рід Зубата мінога - Eudontomyzon Regan, 1911 & & & & & & \\
\hline & Мінога карпатська - E.danfordi Regan, 1911 & + & + & + & + & + & - \\
\hline & Ряд лососеподібні - Salmoniformes Bleeker, 1859 & & & & & & \\
\hline & Родина лососеві - Salmonidae Cuvier, 1816 & & & & & & \\
\hline & Рід Харiуc - Thymallus Cuvier, 1829 & & & & & & \\
\hline 2 & Харіус європейський - T. thymallus L.,1758 & + & + & + & + & + & - \\
\hline \multirow[t]{2}{*}{3} & Лосось дунайський - H. hucho - Linnaeus, 1758 & + & - & + & + & + & - \\
\hline & Рід Лосось - Salmo Linnaeus, 1758 & & & & & & \\
\hline \multirow[t]{4}{*}{4} & Форель струмкова - S. trutta m. fario L., 1758 & + & + & + & + & + & - \\
\hline & Ряд щукоподібні - Esociformes Bleeker, 1858 & & & & & & \\
\hline & Родина щукові - Esocidae Cuvier, 1816 & & & & & & \\
\hline & Рід Щука - Esox Linnaeus, 1758 & & & & & & \\
\hline \multirow[t]{4}{*}{5} & Щука звичайна - E. luceus Linnaeus,1758 & - & - & - & - & + & + \\
\hline & Ряд тріскоподібні - Gabiformes Goodrich, 1909 & & & & & & \\
\hline & Родина миневі - Lotidae Bonaparte, 1837 & & & & & & \\
\hline & Рід Минь - Lota Oken, 1817 & & & & & & \\
\hline \multirow[t]{4}{*}{6} & Минь річковий - L. lota Linnaeus, 1758 & - & - & + & - & + & - \\
\hline & Ряд скорпеноподібні - Scorpaeniformes Risso, 1826 & & & & & & \\
\hline & Родина рогаткові - Cottidae Bonaparte, 1831 & & & & & & \\
\hline & Рід Бабець - Cottus Linnaeus, 1758 & & & & & & \\
\hline 7 & Бабець строкатоплавцевий - C. poecilopus H., 1837 & + & + & + & + & + & - \\
\hline \multirow[t]{4}{*}{8} & Бабець європейський - C. gobio Linnaeus, 1758 & - & - & - & - & + & - \\
\hline & Ряд окунеподібні - Perciformes Bleeker, 1859 & & & & & & \\
\hline & Родина окуневі - Percidae Cuvier, 1816 & & & & & & \\
\hline & Рід Окунь прісноводний - Perca Linnaeus, 1758 & & & & & & \\
\hline \multirow[t]{2}{*}{9} & Окунь звичайний - P. fluviatilis Linnaeus, 1758 & - & - & - & - & - & + \\
\hline & Рід Чоп - Zingel Cloguet, 1817 & & & & & & \\
\hline 10 & Чоп великий - Z.zingel Linnaeus, 1766 & - & - & + & + & + & - \\
\hline \multirow[t]{2}{*}{11} & Чоп малий - Z.streber Siebold, 1863 & + & + & + & + & - & - \\
\hline & Рід Йорж - Gumnocephalus Bloch, 1793 & & & & & & \\
\hline \multirow[t]{4}{*}{12} & Йорж звичайний - G. cernuus Linnaeus, 1758 & - & - & - & - & - & + \\
\hline & Ряд коропоподібні - Cypriniformes Goodrich, 1909 & & & & & & \\
\hline & Родина коропові - Cyprinidae Fleming, 1822 & & & & & & \\
\hline & Рід Головень - Sgualius Bonaparte, 1837 & & & & & & \\
\hline \multirow[t]{2}{*}{13} & Головень європейський - S. cephalus L., 1758 & - & - & - & + & + & - \\
\hline & Рід Ялець - Telestes Bonaparte, 1840 & & & & & & \\
\hline 14 & Ялець-андруга закарпатський L. Souffia agassii Valensiennes, 1844 & + & + & + & + & + & - \\
\hline \multirow[t]{2}{*}{15} & Ялець-андруга європ. T.souffia Risso, 1827 & - & - & - & + & + & - \\
\hline & Рід Плітка - Rutilus Rafinesgue, 1820 & & & & & & \\
\hline 16 & Плітка - R.virgo Heckel 1852 & - & - & - & - & + & - \\
\hline \multirow[t]{2}{*}{17} & Плітка звичайна - R. rutilus Linnaeus, 1758 & + & + & + & + & + & - \\
\hline & Рід Краснопірка - Scardinius Bonaparte, 1837 & & & & & & \\
\hline \multirow[t]{2}{*}{18} & Краснопірка звич. - S.erythrophthalmus L. 1758 & - & - & - & - & - & + \\
\hline & Рід Підуст - Chondrostoma Agassiz, 1832 & & & & & & \\
\hline \multirow[t]{2}{*}{19} & Підуст звичайний С. nasus Linnaeus, 1758 & + & + & + & + & + & + \\
\hline & Рід Бистрянка - Alburnoides Jeitteles, 1861 & & & & & & \\
\hline \multirow[t]{2}{*}{20} & Бистрянка звичайна - A. bipunctatus Bloch, 1782 & + & + & + & + & + & - \\
\hline & Рід Верховодка - Alburnus Rafinesgue, 1920 & & & & & & \\
\hline \multirow[t]{2}{*}{21} & Верховодка звичайна - A. alburnus Linnaeus, 1758 & + & + & + & + & + & - \\
\hline & Рід Гольян - Phoxinus Rafinesgue, 1820 & & & & & & \\
\hline 22 & Гольян звичайний - P. phoxinus Linnaeus, 1758 & + & + & + & + & + & + \\
\hline
\end{tabular}


Рід Пічкур - Gobio Cuvier, 1816

23 Пічкур звичайний - G. gobio Linnaeus, 1758

24 Пічкур карпатський - G.carpathicusVladykov, 1925

25 Пічкур дунайський - G.uranoscopus Agassiz, 1828

26 Білоперий пічкур дунайський - Romanogobio vladykovi Fang, 1943

Рід Марена - Barbus Cuvier, 1816

27 Марена звичайна - B. barbus Linnaeus, 1758

28 Марена дунайсько-дністровська B.petenyi Heckel, 1852

Рід Карась - Carassius Jarocki, 1822

29 Карась звичайний - C. carassius Linnaeus, 1758

Рід Лин - Tinca Cuvier, 1816

30 Лин звичайний - T. tinca Linnaeus, 1758

Родина в'юнові - Cobitidae Swainson, 1839

Рід Щипавка - Cobitis Linnaeus, 1758

31 Щипавка звичайна - C. taenia Misgurnus

32 Щипавка гірська - C. aurata De Filippi, 1863

Рід В'юн - Misgurnus La Cepede, 1803

33 В'юн звичайний - M. fossilis Linnaeus, 1758

Родина баліторові, річкові слижі - Balitoridae Swainson, 1939

Рід Вусатий слиж - Barbatula Linck, 1790

34 Вусатий слиж європейський - B.barbatula, L. 1758

Варто зазначити, що автохтонна іхтіофауна КБЗ характеризується в основному первозданністю складу угрупувань та видів сформованих еволюційно і дотепер залишається порівняно природним, наявністю 8, $82 \%$ лососевих. Проте виявлено деяке виснаження рибних запасів. А зменшення чисельності популяції від ефективного до критичного рівня супроводжується погіршенням важливих біологічних показників, виживаності зародків, личинок, швидкості росту, ефективності засвоюваності корму, призводить до втрати контролю і регуляції генотипової та фенотипової мінливості. Тому так важливо мати ефективну чисельність аборигенних популяцій, при яких вони можуть підтримувати високий рівень генетичного різноманіття, забезпечити цинотичну повночленність, екосистемну цілісність, біомну репрезентативність.
Варто зазначити, що, крім аборигенних, виявлено нові, нехарактерні види -8 атипових таксонів (табл. 4), що пов'язано з інтродукцією, інвазіями, господарською діяльністю людини, кліматичними змінами. Зокрема, після 2000 року у високогір’ї Карпат температура найтеплішого місяця збільшилась приблизно на $2{ }^{\circ} \mathrm{C}$ порівняно зі стандартною кліматичною нормою (Kanarskyi, 2016). Змінюється хімізм води через випадання кислотних атмосферних опадів. Протікаючи через або недалеко від 18 поселень із населенням близько 100 тис. осіб, зазнають погіршення санітарного стану. Відбувається неконтрольоване потрапляння у природні водотоки із розміщених вздовж берегів Чорної Тиси господарств 3 розведення і вирощування микіжі прісноводної й інших невластивих риб та демонстраційного іхтіологічного господарства КБЗ.

\section{Таблиця 4}

Інвентаризаційний список алохтонних видів риб водотоків КБЗ в розрізі масивів

\begin{tabular}{|c|c|c|c|c|c|c|c|}
\hline \multirow{2}{*}{$\begin{array}{c}\text { № } \\
\text { 3a/ח }\end{array}$} & \multirow{2}{*}{$\begin{array}{c}\text { Таксономічний статус, назва виду } \\
\text { (українською, латинською) }\end{array}$} & \multicolumn{6}{|c|}{ Назва масивів } \\
\hline & & CB & ЧО & MP & УШ & KT & ДН \\
\hline \multirow{7}{*}{1} & Ряд лососеподібні - Salmoniformes Bleeker, 1859 & & & & & & \\
\hline & Родина лососеві - Salmonidae Cuvier, 1816 & & & & & & \\
\hline & Рід Тихоокеанська форель - Parasalmo Vladykov, 1972 & & & & & & \\
\hline & Микіжа прісноводна (форель райдужна)- Parasalmo mykiss Walbaum, 1792 & + & + & + & - & + & - \\
\hline & Ряд коропоподібні - Cypriniformes Goodrich, 1909 & & & & & & \\
\hline & Родина коропові - Cyprinidae Fleming, 1822 & & & & & & \\
\hline & Рід Товстолобик білий - Hypophthalmichthys Bleeker, 1859 & & & & & & \\
\hline \multirow[t]{2}{*}{2} & Товстолобик білий амурський - H. molitrix Valenciennes, 1844 & - & - & - & - & - & + \\
\hline & Рід Короп - Cyprinus Linnaeus, 1758 & & & & & & \\
\hline \multirow[t]{2}{*}{3} & Короп звичайний - C. carpio Linnaeus, 1758 & - & - & - & - & - & + \\
\hline & Рід Карась - Carassius Jarocki, 1822 & & & & & & \\
\hline 4 & Карась китайський - C. auratus Linnaeus, 1758 & - & - & - & + & + & + \\
\hline \multirow[t]{2}{*}{5} & Карась сріблястий - C. gibelio Bloch, 1782 & - & - & - & + & + & + \\
\hline & Рід Чебачок - Pseudorasbor Bleekera, 1859 & & & & & & \\
\hline \multirow[t]{4}{*}{6} & Чебачок амурський - P. parva Temminck et Schlegel, 1846 & - & - & + & - & + & + \\
\hline & Ряд окунеподібні - Perciformes Bleeker, 1859 & & & & & & \\
\hline & Родина центрархові - Centrarchidae Bleeker, 1859 & & & & & & \\
\hline & Рід Сонячна риба - Lepomis Rafinesgue, 1819 & & & & & & \\
\hline \multirow[t]{3}{*}{7} & Сонячна риба синьозяброва - L. gibbosus L, 1758 & - & - & - & - & + & + \\
\hline & Родина головешкові - Odontobutidae Hoese et Gill, 1993 & & & & & & \\
\hline & Рід Головешка - Perccottus Dybowski, 1877 & & & & & & \\
\hline 8 & Головешка ротань - P. glenii Dybowski, 1877 & & & + & - & + & + \\
\hline
\end{tabular}


Частка туводних, нетипових, риб складає 19,05\%. Присутні вселенці накладають певний відбиток, займаючи місця мешкання аборигенів, витісняючи їх 3 власної екологічної ніші. Вони конкуренти за спектром живлення. Пластичні, термостійкі у зимовий i літній періоди, невибагливі до гідрохімічного складу водойм та освоюють абсолютно нові для себе ареали внаслідок експансії (Теrpay, 2019). Поряд з цим головешка ротань, сонячна риба синьозяброва, чебачок амурський, микіжа прісноводна інтенсивно поїдають ікру та мальків раритетних і цінних іхтіоценозів.

Загалом у досліджуваних акваторіях від 180 до 1880 м н. р. м. ми зафіксували 42 види круглоротих і риб, які належать до 7 рядів, 11 родин, 33 родів. Додатково ідентифікували 12 неописаних. Ріст загальної кількості видів на 66,67 \% відбувся за рахунок алохтонів. Зважаючи на їхню здатність акліматизуватися та натуралізуватися, вони дуже небезпечні для екосистеми КБЗ. Наведені дані можуть змінюватися в міру подальшого вивчення, проведення ревізії та завдяки використанню сучасних біохімічних $\mathrm{i}$ генетичних досліджень.

Порівняльний аналіз отриманих результатів і літературних джерел показав, що у водотоках КБЗ мешкає 54,54 \% видового складу риб та круглоротих від наявних в Закарпатській області. Раритетний іхтіофонд досліджуваної території вирізняється наявністю малочисельної групи видів національного рівня раритетності та значною групою регіонально рідкісних видів. Серед них 11 таксонів занесено до Червоної книги України, 2009 та 17 - до Червоної книги Закарпаття, 2011. Отже, можна констатувати, що теперішній природоохоронний статус достатній для природної саморегуляції та відтворення чисельності, збереження вказаних і аборигенних популяцій in situ.

В процесі роботи з'ясували: незалежно від масиву КБ3, домінуючий комплекс складають індиферентні до швидкої течії аборигени, котрі здійснюють сезонні міграції. Особини іхтіоценозу зберігають просторове розміщення, видно, це пов'язано з відповідною диференціацією біотопів, перепадами висот, якістю та температурою води, гідрологічними особливостями, кормовою базою та іншими чинниками. Високогірні простори заселені стенотермними холодолюбними, майже ідентичними із тими, що не входять у територію КБЗ. Значну цінність становлять окремі види. 3 цієї причини встановлено екологічну амплітуду форелі струмкової та харіуса європейського відповідно від 500-550 і 300 м над рівнем моря (м н. р. м.) до 1280 i 850 м н. р. м. Вони дуже вимогливі до кисневого i температурного режимів, мають плями та незвичайне забарвлення. За кількістю кисню, необхідного для нормального життя і розвитку, струмкова форель належить до мегаоксифільних - 7-11 О2 cм 3 /л, харіус європейський до мезооксифільних - 5-8 О2 $\mathrm{cm}^{3} /$ л. Менш вимогливі олігооксифільні - 3-5 cм³/л - дунайський лосось, щука, окунь звичайний. Витримують понижений рівень 0,5-2,0 $\mathrm{cm}^{3} /$ л короп, карась, лин, в'юн.

На масивах КБЗ фауна риб розподіляється доволі нерівномірно. Максимальна різновидність спостерігається у КТ і нараховує 34 види, мінімальна у ДН - 17, 3 яких 41,18\% алохтонні, за можливості запливу в річку Хустянку з Тиси та річки Ріка 31 виду. Але урбанізований фрагмент русла р. Хустянка в межах м. Хуст цьому чинить перепони. Безперервний скид господарсько-побутових і промислових вод утворив своєрідний екологічний замок, насичений біогенними, органічними та токсичними сполуками.

Провідним показником систематичної структури іхтіофауни є кількість родин, який відображає головні властивості комплексу (табл. 5).

\section{Таблиця 5}

Систематична структура іхтіофауни КБЗ

\begin{tabular}{|c|c|c|c|c|c|c|}
\hline \multirow{3}{*}{ № за/п. } & \multicolumn{3}{|c|}{ Автохтонні види } & \multicolumn{3}{|c|}{ Алохтонні види } \\
\hline & \multirow{2}{*}{ назва родин } & \multicolumn{2}{|c|}{ кількість видів } & \multirow{2}{*}{ назва родин } & \multicolumn{2}{|c|}{ кількість видів } \\
\hline & & абсолютна & $\%$ & & абсолютна & $\%$ \\
\hline 1 & міногові & 1 & 2,94 & - & - & - \\
\hline 2 & лососеві & 3 & 8,82 & - & 1 & 12,50 \\
\hline 3 & щукові & 1 & 2,94 & - & - & - \\
\hline 4 & миневі & 1 & 2,94 & - & - & - \\
\hline 5 & рогаткові & 2 & 5,88 & центрархові & 1 & 12,50 \\
\hline 6 & окуневі & 4 & 11,76 & - & - & - \\
\hline 7 & коропові & 18 & 52,96 & - & 5 & 62,50 \\
\hline 8 & в’юнові & 3 & 8,82 & головешкові & 1 & 12,50 \\
\hline 9 & баліторові & 1 & 2,94 & - & - & - \\
\hline Всього & & 34 & 100,00 & & 8 & 100,00 \\
\hline
\end{tabular}

Як видно 3 наведених даних, конспект досліджуваних круглоротих і риб нараховує 11 родин. Акцент робимо на автохтонному та унікальному, раритетному різноманіттю. Перше місце в родинному спектрі серед автохтонних посідають коропові - 18 видів, або $52,96 \%$. Висока позиція окуневих. Наступне положення розділили лососеві із в'юновими, родини налічують по 3 види і займають 8,82 \% кожна. Алохтонні, маючи 4 родини, налічують 8 видів, масовішою виявилась також родина коропових $(5 ; 62,50 \%)$ і в абсолютному, і у відсотковому плані.

\section{Висновки}

1. Іхтіофауністичне дослідження у межах природних водотоків КБЗ дозволило встановити - його малі 
річки і потоки стали основними резерватами для аборигенних і лососевих риб, які тут вегетують та складають фонове видове різноманіття. Певний підсумок вивченості іхтіофауни, уточнення назв може бути покладено в основу єдиної номенклатури міног і риб водотоків КБЗ. Засвідчено порівняно добру репрезентативність видів - 54,54 \% від усіх, що мешкають у водоймах Закарпатської області.

2. Природоохоронна екоструктура, збережені оселища створюють необхідні умови розвитку лососевим, рідкісним, зникаючим та раритетним рибам найвразливішій складовій іхтіофауни - розселюватися їм у води інших територій. Завдяки цьому опис нових видів риб допоможе більш повно представити функціонування екосистеми КБЗ і зрозуміти, які кроки потрібно зробити для збереження біорізноманіття, оскільки заповідник є ядром генофондових ресурсів перерахованих видів для річкової екосистеми Верхньо-Тисянського рибовідтворювального комплексу ріки Тиса.

3. Досить високе положення у спектрі таксонів лососевих підтверджує чистоту вод КБЗ, включаючи верхів'я приток і самої річки Тиса. Присутність карася сріблястого та інших риб з високою екологічною валентністю вказує на погіршення якості води за гідрохімічними і еколого-токсикологічними показниками (Romanenko \& Medovnyk, 2017). Зміщення систематичної структури риб на нижчих ділянках Тиси свідчить про антропогенний вплив.

4. Природна структура іхтіофауни забезпечує стійкість і стабільність функціонування не тільки гідро-, а й екосистеми КБЗ. За умови підтримання хоча б теперішнього гідрохімічного режиму можна зберегти наявну чисельність видів і популяцій у найближчій перспективі. Розуміння змін структури іхтіопопуляцій, видового різноманіття від змін абіотичних умов та інвазії сторонніх видів риб є важливим для науковців і екологів, дозволяє прогнозувати належний стан охорони водних екосистем заповідника в конкретний момент.

5. Систематичний моніторинг виступає однією 3 важливих складових у існуванні, збереженні, відновленні генофондових ресурсів риб та біоти КБЗ, тому можна рекомендувати проведення таких досліджень на інших природно-заповідних територіях області та Карпатського регіону.

\section{References}

Akimov, I. A. (2009). Chervona knyha Ukrainy. Tvarynnyi svit. K.: Hlobalkonsaltyh (in Ukrainian).

Horbachova, L. O., \& Khrystiuk, B. F. (2016). Hidrolohichne raionuvannia terytorii ukrainy za umovamy formuvannia richnoho stoku vody na osnovi kryvykh endriusa. Ukrainskyi heohrafichnyi zhurnal, 3, 27-33. doi: 10.15407/ugz2016.03.027.

Kanarskyi, Yu. V. (2016). Klimatychni zminy v rehioni Ukrainskykh Karpat na pochatku KhKhI stolittia ta yikh vplyv na biotychne riznomanittia. Naukovi osnovy zberezhennia biotychnoi riznomanitnosti, 7(14), 15-36 (in Ukrainian).

Meteleshko, O. Iu., \& Potish, L. A. (2011). Chervona knyha Ukrainskykh Karpat. Tvarynnyi svit. Uzhhorod: Karpaty (in Ukrainian).

Mizhnarodnyi kodeks zoolohichnoi nomenklatury (2003). Vydannia chetverte. Ukhvalenyi Mizhnarodnym soiuzom biolohich-nykh nauk. Pereklad z anhliiskoi i frantsuzkoi. K.: Biblioteka ofitsiinykh vydan (in Ukrainian).

Movchan, Yu.V. (2011). Ryby Ukrainy (vyznachnyk dovidnyk). Kyiv. Vydavnytstvo "Zoloti vorota" (in Ukrainian).

Romanenko, V. D., \& Medovnyk, D. V. (2017). Vydova ta ekolohichna kharakterystyka ikhtiofauny malykh richok urbanizovanykh terytorii. Hidrobiolohichnyi zhurnal, 53(4), 3-12 (in Ukrainian).

Terpai, V. P. (2018). Nehatyvnyi vplyv diialnosti liudyny ta alokhtonnykh vydiv ryb na mistsevu ikhtiofaunu Zakarpattia. Materialy mizhnarodnoi naukovo - praktychnoi konferentsii. 22-25 zhovtnia 2018. Rakhiv, 464-478 (in Ukrainian).

Terpay, V. (2019). Threats to salmon and endangered fish species in Tysa river basin within trans Carpathian region (review). Scientific Messenger of LNU of Veterinary Medicine and Biotechnologies. Series: Agricultural Sciences, 21(91), 37-48. doi: 10.32718/nvlvet-a9107.

Turianyn, I. I. (1982). Ryby karpatskykh vodoim. Uzhhorod. Vydavnytstv Karpaty (in Ukrainian). 